\title{
Preventive Transcendental Of Mass Violence Crimes
}

\author{
Purwadi Wahyu Anggoro \\ Curriculum Bureau Staff, Lemdiklat Polri (Education and Training Institute, \\ Republic of Indonesia National Police) \\ Universitas Muhammadiyah Surakarta \\ purwadi.tp94@gmail.com
}

DOI: https://doi.org/10.23917/jtl.v1i2.9155

\author{
Submission Track: \\ Received:
}

11 November 2019

Final Revision:

05 Februari 2020

Available online:

14 Februari 2020

Corresponding

Author:

Purwadi Wahyu

Anggoro

purwadi.tp94@gmail.com

\begin{abstract}
Purpose: This article aims to explain the causes of criminal acts of violence that occur in cases of violence involving the masses and explicate the concept of preventing violent crimes involving masses who have a transcendental paradigm.

Methodology: This research was qualitative nondoctrinal research. The strategy of applying Preventive Law with a Transcendental paradigm as a concept of preventing criminal acts of mass violence with religious nuances is as a way to reduce the emotions of the masses and eliminate the intention of the masses to commit acts of violence. The sources of data were in the form of research and interviews of cases of mass violence. The data analysis used interpretation techniques based on the (premise) stage of mass violence, according to Niel Smelser and transcendental preventive patterns in accordance with the literature reviews of books and scientific journals.
\end{abstract}

Results: The results showed that violence is an act against the law (onrechtmatige daad), where it is the human state of nature. In the crowd, people will imitate other people's actions, lose control, and take aggressive actions. The law is a tool for social engineering to prevent crime, maintain an orderly society, and provide protection for citizens. Law enforcement is prioritized using soft methods (the soft hand of society) to prevent violence from happening with a transcendental paradigm approach to restoring human nature, according to Surah Ali Imran (3) paragraph 110, namely amar ma'ruf, which contains transcendental ethical values.

Importance: This research is useful in the implementation of the Transcendental Preventive Law for law enforcement officers, in this case, the National Police, as an effort to break the 4th stage, namely the stage before triggering incidents occur. It is intended that at the time of mass violence, the Preventive Transcendental Law can cool down the emotions of the masses while at the same time restore human awareness that peace, compassion, and the world and its contents are a gift that must be accountable to God Almighty.

Originality/Novelty: Transcendental Preventive Law is an effort to prevent violent crime in mass violence that is based on transcendental principles, by giving a religious touch to remind the masses that violence is a sinful act and to remind the existence of God Almighty.

Keywords: onrechtmatige daad, state of nature, the soft hand of society, preventive transcendental 


\section{INTRODUCTION}

Violence is an inevitability experienced by all countries; conflict and war cause a political escalation in several other countries to increase. ${ }^{1}$ Since the New Order government until now, in Indonesia, there have been cases of violence that have caused material or life casualties. President Soeharto resigned in 1998, preceded by violent conflict, the process of replacing state leaders was also a period of democratic transition in Indonesia.

Violence is a form of crime, which is done by someone or more that causes injury, both physically and non-physically to others, and violence involving the masses is mentioned in Article 170 of the Criminal Law Code. Furthermore, it is an act that causes a person not to actualize himself, caused by forms of oppression directed at him. It means that violence causes a person to be harmed or experience a negative impact in various forms. $^{2}$

Norms are a set of life instructions that govern various rules in a society or nation that require the regulations to be obeyed by every society. Humans are always bound by values, morals, and laws that function as a regulator of all human behavior. If there is a violation, there will be actions from the government. ${ }^{3}$

Values are devices to uphold order, justice, and social order. Whereas, morals are the foundation of human behavior so that life can proceed according to the norms of life. The law itself is a control tool to regulate the rights and obligations of every human being in running life, so that order and obedience to values, morals, and laws can reflect the culture and character of a nation.

The low level of public trust in legal institutions and no longer trust the existing legal process are our inability to see human life with a complete view, causing a crisis in the intellectual, moral, and spiritual dimensions of humans. People can no longer focus on one

\footnotetext{
${ }^{1}$ Robert Malley, Feature: 10 Conflicts to Watch in 2018. Jurnal Foreign Policy. 4 November 2018. Page 1.

2 John Galtung.Transcend and Transform, An Introduction to ConflictWork. London: Pluto Press. 2004. Page 140.

${ }^{3}$ E. Utrecht. Pengantar Dalam Hukum Indonesia. Jakarta: Balai Buku Ichtiar. 1962. Page 3.
} 
object separated from their environment but let the object unite with their environment, as referred to by Capra as a turning point. ${ }^{4}$

Acts against the law (onrechtmatige daad) is an act committed by someone who does not obey or break the law. Understanding acts against the law is not only seen because it violates the provisions of the Act, but there is also an element of intent. Understanding illegal acts in a broad sense consist of four things, namely: 1) violating the rights of others; 2) contrary to the legal obligations of the offender; 3) contrary to decency; and 4) contrary to propriety in taking into account the self-interest and property of others in the community life. ${ }^{5}$

In the crowd, people will feel that no one else is paying attention and knows him so that it is easy to lose control, allowing someone to take aggressive actions, and easy to imitate the actions of others. ${ }^{6}$ Increasingly, humans consider violence as a normal thing, and understand it as part of the reform, so that eventually, humans seem to be numb to the indications of violence. ${ }^{7}$

Violence can be created, provoked, and cultured so that a culture of violence or a culture that produces violence is formed. ${ }^{8}$ Violence becomes a pattern of human behavior as if humans are not able to escape from acts of violence, even considered as a necessity or as a choice without alternatives. ${ }^{9}$ The police, as the person in charge of public security, must act quickly to prevent violence involving the masses by using a preventive legal approach as a preventive measure.

\section{FORMULATION OF THE PROBLEM}

Based on the description above, the problem can be proposed, namely, what is the cause of the violent crime that occurred in cases of violence involving the masses?

\footnotetext{
${ }^{4}$ Fritjop Capra in Suteki, The Turning Point (Science, Society, and The Rising Culture), London: Flamingo, 1983. Presented at Seminar Nasional MIH Unissula on Themes: Penanggulangan Tindakan Eigenrichting (Main Hakim Sendiri) Yang Dilakukan Oleh Kelompok Masyarakat. Semarang, 9 Desember 2017.

${ }^{5}$ Munir Faudi. Perbuatan Melawan Hukum. Bandung: PT. Citra Aditya Bakti. 2002. Page 3.

${ }^{6}$ Ronny Nitibaskara, Meningkatnya Derajat Kekerasan Kolektif. Kompas, Saturday, 17 Juni 2002.

7 Arinto Nurcahyono, Kekerasan Sebagai Fenomena Budaya: Suatu Pelacakan Terhadap Akar Kekerasan Di Indonesia, Jurnal Mimbar, Volume XIX No. 3 Juli - September 2003. Page 241.

8 Julia L. Suryakusuma, Budaya Kekerasan, atau Budaya yang Menghasilkan Kekerasan, in Arinto Nurcahyono, Kekerasan Sebagai Fenomena Budaya: Suatu Pelacakan Terhadap Akar Kekerasan Di Indonesia, Jurnal Mimbar, Volume XIX No. 3 Juli-September 2003. Page 243.

${ }^{9}$ Israel W. Charny (ed), Strategies Against Violence: Design for Nonviolen Change. Colorado: Westview Press, Inc., 1978. Page 244.
} 
Moreover, how is the concept of preventing violent crime involving the masses who have a transcendental paradigm?

\section{RESEARCH METHODOLOGY}

This research was based on legal research, which was conducted with a qualitative non-doctrinal approach. ${ }^{10}$ In this study, law is not only conceptualized as a whole of the principles and rules governing human life in society but also includes the institutions and processes that embody the enactment of the rules in society, as the embodiment of the symbolic meanings of the social actors, as manifested and observed in and from the actions and interactions between them. Thus, this study would try to see the relationship between legal factors with extra-legal factors related to the object under study.

\section{DISCUSSION}

From the data of the Crisis Control Center, Operational Bureau, National Police Headquarters of the Republic of Indonesia, during the last 3 (three) years, namely 2016, 2017, and 2018, there have been 141 mass clashes/social conflicts in Indonesia, with details in 2016 occurred 60 cases, in 2017 occurred 52 cases, and in 2018 there were 29 cases. ${ }^{11}$ The purpose of law enforcement is to achieve peace in society. The degree of community legal compliance with the law is one indicator of the functioning of the law in question. ${ }^{12}$ The scope of duties and objectives of the criminal justice system is to prevent people from becoming victims of crime, ${ }^{13}$ maintain an orderly society, and to protect community members from crime, loss, or unjustified harm done by others.

Roscoe Pound argues that the primary function of law is to protect the interests that exist in society; three interests must be protected by law, namely:

1. Public Interest is the demand for the needs or desires in the social life of a politically organized society regarding the life of the organization.

2. Society Interest is the demands, needs, or desires in the social life of civil society, among others, for the benefit of a better environment.

\footnotetext{
10 Soetandyo Wignjosoebroto, Silabus Metode Penelitian Hukum, Program Pascasarjana Universitas Airlangga, Surabaya. Pages 1 and 3

11 Data Pusat Pengendali Krisis, Biro Operasional Polri, Mabes Polri, Jakarta. 2018.

${ }^{12}$ Soerjono Soekanto, Faktor-Faktor Yang Mempengaruhi Penegakan Hukum. Cetakan Kelima. Jakarta: Raja Grafindo Persada. 2004. Page 42.

13 Mardjono Reksodiputro. Kriminologi dan Sistem Peradilan Pidana. Jakarta: PPKPH UI. 1994. Page 140.
} 
3. Individual Interest is a demand, need, or desire that immediately arises in an individual's life and is related to an individual's life.

The law must be seen as a social institution that functions to meet social needs to the full, and then the law is strongly influenced by components outside the law. Law is influenced by the needs of community, ideology, politics, society, economy, and culture. In modern society, the law has an essential meaning. In addition to strengthening the patterns of habits and behavior in society, the law also functions as a tool to direct goals, eliminate inappropriate habits, and create new patterns of habit in society, so that the law understood as a means of changing society (social engineering by the law).

Law enforcement officers must correctly understand logic, history, traditions, customs, and guidelines for correct behavior so that justice can be upheld and used as a means of developing society and a means of community renewal in development. Law is a tool of social engineering and social control that aims to create harmony in society to meet their needs. ${ }^{14}$

The police in carrying out their duties prioritize a more lenient and non-hurtful way to realize a Civilian Police, that is, by applying the soft hand of society approach and aligning positions between the police and the community. The soft approach of the police is a preventive law to provide protection, safeguard, and services to the public, as described in Article 5 and Article 14 Paragraph (1) of Law no. 2 of 2002 concerning the Indonesian National Police.

The soft hand of society approach is a police preventive measure to restore Indonesia's noble culture, politeness, and high manners, with the concept of a transcendental paradigm as an effort to restore human nature, cleanse themselves, and restore human awareness that this world is a gift from God Almighty that must be accounted.

In the Theory of Mass Violence, basically, every human being has a destructive instinct, namely the instinct of violence, but the perpetrators commit violence without guilt, ignoring courtesy norms, religious norms, and humanity. Every human being has the potential to do violence because the act of violence is a manifestation of the basic aggressive and destructive nature of every human being. ${ }^{15}$

\footnotetext{
${ }^{14}$ Ahmad Kamil, Kaidah-kaidah Hukum Yurisprudensi, Kencana, Jakarta. 2005. Page 94.

15 Giovanni Paoletti, Durkheim's 'Dualism of Human Nature': Personal Identity and Social Links.Jurnal Durkheimian Studies/Études Durkheimiennes, Eds. 18. 2012. Pages 61-80.
} 
Violence is a state of nature, which is controlled by irrational, anarchistic, and mechanistic impulses that envy and hate each other so that human becomes rude, evil, savage, and short thought. As a figure of homo homini lupus, man is a wolf to the others, and as a result, the war is all against all (not yet omnium contra omnes). ${ }^{16}$

Humans are aggressive in nature due to the existence of animal power in themselves that encourage violence or persecution. In Ibn Khaldun's terminology, it is called ashobiyah; that is, humans are not willing if one or several members of their group experience difficulties or are insulted; with all their efforts, they will try to restore their group's honor. ${ }^{17}$

The mass has an inner bond due to the equality of will, equality of purpose, equality of ideas, and so on. The masses have their norms in common because the masses have their own rules, habits, and so on. ${ }^{18}$

Neil J. Smelser, in the Theory of Collective Behavior, explains that the events of mass violence have several stages that must be passed, cannot occur suddenly. There are steps (premises) that must go sequentially; if one premise does not work, then mass violence will be failed or will not occur, namely:

1) Structural Conduciveness, a structural condition of the community that has the potential for collective behavior.

2) Structural Strains, the emergence of social tensions in society caused by structured facts, such as legal uncertainty, conflict, issues, and economic inequality, or social inequality that has the potential to cause social unrest.

3) Generalized Beliefs, interpretations that generally apply when a group of people experiences disharmony or conflict with other groups; will try to find those who should be responsible for causing these conditions.

4) Precipitating Factors, which are situational factors as structural drivers, structural tension in general, and the presence of triggering factors that cause collective behavior.

5) Mobilization for Actions, collective violence that requires mobilized masses and leaders (provocateurs) to act, the masses act as rioters.

\footnotetext{
${ }^{16}$ Franz Magnis Suseno, Etika Politik, Jakarta: Gramedia. 1987. Pages 200-207.

${ }^{17}$ Hakimul Ikhwan Affandi, Akar Konflik Sepanjang Zaman: Elaborasi pemikiran Ibn Khaldun, Yogyakarta: Pustaka Pelajar, 2004. Page 82.

18 Jaap Van Ginneken. Crowds, Psychology, and Politics, 1871-1899. Cambridge, England, UK: Cambridge University Press, 1992. Page 131.
} 
6) Failure of Social Control, social control institutions that do not work when social unrest occurs. For example, the authorities are late coming to the scene so that their role as social control does not work. ${ }^{19}$

Triggering incidents are small conflicts that have an individual nature or involve only a few people in which the Indonesian National Police must immediately deal with quickly, precisely, and efficiently. If a small conflict is not dealt with quickly and appropriately, then the conflict will be seen as a "form of resistance" from the real "enemy" movement that has been identified in the previous process.

According to the analysis of the stages of the occurrence of mass violence from Neil J. Smellser, the steps (premises) must go sequentially; then, if one premise does not work, mass violence will fail. Therefore, the opportunity for the police to do prevention by implementing preventive law on the fourth premise is before the triggering factors occur.

Based on the understanding of the Transcendental Paradigm, humans are God's complex creatures; humans are a combination of physical (material) and spiritual (nonmaterial) elements. A spiritual element is a form of correlation between creatures and their creators. If science is a way to achieve happiness (material), spiritual understanding (nonmaterial) is used to understand the truth of God the Perfect, both through His words contained in the scriptures and the instructions of the universe. Kuntowijoyo interprets transcendence in the sense of faith in God derived from Surah Ali Imran 110 by placing three transcendental pillars, namely humanization (ta'muruna bil-ma'ruf), liberation (tanhauna anil munkar), and transcendence (tu'minuna billah).

Islam is a religion of peace that teaches an attitude of peace and the search for peace. Islam has never justified the practice of using violence in spreading religion, religious understanding, and political understanding. The Koran is a paradigm; a transcendental structure means recognizing that the Koran must be understood as having a transcendental building of ideas, an order, or a system of ideas, which is autonomous and perfect.

Religious values will be an essential part of the process of building civilization, namely: 1) Humanization, which is a translation of amar ma'ruf that means to advocate or uphold virtue. Humanization means humanizing fellow human beings, eliminating the "material," dependence, violence, and hatred of human nature; 2) Liberation, which is the

${ }^{19}$ Neil J. Smelser., Theory of Colective Behavior. New York: A Free Press Paperback, 1971. T. Lickona, Educating for Character How Our Schools Can Teach Respect and Responsibility. New York-Toronto-LondonSydney-Auckland: Bantam Books. 1992. Hal. 18. 
meaning of nahi munkar in accordance with the principles of socialism. Liberation is in the context of science, based on transcendental noble values; and 3) Transcendence, which is the concept of tu'minuna billah (having faith in Allah).

Based on Preventive Legal Theory, the function of the Police, who is as a community safeguard and law enforcer, is responsible for maintaining public order so that community members can live and work in a safe and secure condition. ${ }^{20}$ The Indonesian Police Preventive Action is an action as an effort to control the society to prevent the possibility of things that are not desirable and to protect the public from bad things that might occur; preventive legal actions are more effective and efficient than recovering the impact of mass violence.

Prevention of transcendental acts of mass violence is done by providing a religious touch with the principle of humanism as enlightenment and the effect of awareness to the masses about the adverse effects of mass violence. In accordance with the principle of humanism, which is a translation of amar ma'ruf, it means as a command to invite or encourage good things and prevent things that are bad for the community.

The police's transcendental preventive action is a preventive measure, as mentioned in Al-Quran Surat Ali Imran (3) verse 110. The verse contains a generally accepted transcendental ethic, for anyone, whether the individual, institution, or collective, namely amar ma'ruf, nahi munkar, and tu'minuna billah.

The National Police applies the keyword "peace" to the prevention of a transcendental paradigm, namely providing a good example (bil ikhsan) to the masses so that humans always do their best, be fair, do good deeds, forbid cruelty (persecution) from fellow humans and invite them always to do good. Kuntowijoyo offers an objectification methodology or methodological objectives, namely translating the subjective values of religion into an objective/factual category that can be understood by everyone without the need to understand the values of origin (religion) and can be agreed upon by anyone without having to approve the original values. Knowing God and Revelation is a crucial element in explaining reality. ${ }^{21}$

\footnotetext{
${ }^{20}$ Harsja W. Bachtiar. Ilmu Kepolisian Suatu Cabang Ilmu Pengetahuan yang Baru. Jakarta: PTIK dan Grasindo. 1994. Page 11.

${ }^{21}$ Kuntowijoyo, Islam Sebagai Ilmu: Epistemologi, Metodologi dan Etika, Teraju PT. Mizan Publika, Jakarta, 2004, Page 27.
} 
This concept is out of the mainstream thinking of legal absolutism by placing law in the whole life for human welfare with a breakthrough (rule-breaking) to prevent mass violence without using criminal legal processes. Behavioral errors occur in societies that are prone to acts of violence. Awareness process needs to be done by giving examples to the public about religious behavior and violence as sins that are prohibited by Allah SWT.

The National Police carries out the principle of preventive measures that are based on a transcendental paradigm by applying prophetic qualities. Those can be applied factually by the National Police in the prevention of criminal acts of mass violence, and in carrying out daily tasks. For example, by outlining the importance of the meaning of peace, elaboration that violence is an act of sin, and prioritizing respect, as well the embodiment of compassion among humans. The National Police makes a preventive effort by promoting a religious and psychological approach so that potential perpetrators of violence are always afraid of sin and remembering their God so that they discouraged and canceled the violence.

The National Police tries to apply a religious thought to restore human nature, cleanse themselves, and restore the perpetrators' awareness that doing good, brotherly relationships, and amar ma'ruf nahi munkar are a gift from Allah SWT, which must be maintained and be accountable. Objectification is a method to present religious values scientifically in the facts of everyday life.

The Transcendental paradigm asserts that a low, which is the fairest and aims to realize the benefit of the people, is only the law of Allah SWT. The Indonesian National Police applies humanist principles based on the elaboration of the behavior of the Prophet Muhammad (PBUH) that teaches humans to be humanistic by humanizing people according to their dignity and values so that every human being has a sense of security and peace in working to fulfill the right to life and meet his needs.

The National Police provides a good example (bil ikhsan) so that humans avoid sin and invite always to do their best, that in Islamic law, the law is mandatory. The police try to give awareness to the masses by using the Asma'ul Husna troops who continue to glorify the name of Allah SWT near the masses as a psychological reminder that there is Allah Almighty so that the masses do not get hotter and more emotional.

The objectification of using the Asmaul Husna Forces is carried out by the police with religious and psychological principles. The method used is to integrate the Accelerate 
Culture Transformation (ACT) approach with Asmaul Husna. There are four steps to the ACT approach, namely: (1) Matching, by using the same clothes as the action participants; (2) Mirroring, by chanting the holy verses of the Koran; (3) Facing, by dealing with a face that is always smiling; and (4) Leading, namely guiding the action participants so that they are not easily affected by provocation. ${ }^{22}$ Religious guidance is carried out by the National Police with the aim that the mass of action is not carried away by emotions that can make the situation worse, thus causing negative impacts that are not in accordance with the objectives of the action.

The National Police provides a religious touch as a transcendental preventive effort to cool the situation while at the same time providing understanding to the masses that disorder, slander, violence, and even riots were actions that were forbidden by Islam and Allah SWT.

\section{CONCLUSION}

Several causative factors of violent crime that occur in cases of violence involving the masses are that 1) every human being has a destructive instinct, namely the instinct of violence, so that the perpetrators can commit violence without guilt, ignoring courtesy norm, religious norm, and humanity. 2) every human being has the potential to commit violence because acts of violence are manifestations of the basic aggressive and destructive nature of every human being. 3) human's aggressive character is a result of animal power in him (ashobiyah); humans will not be willing if one or several members of his group have difficulty or humiliated that with all their efforts, they will restore the group's honor. 4) the mass has an inner bond due to the equality of will, equality of purpose, equality of ideas. 5) the mass is affected by external environmental conditions so that the masses have the same norm; it is because they have their own rules and habits as a mass.

The concept of preventing violent crimes involving the masses using the transcendental paradigm is an effort to prevent violence so that the police do not need to act legally repressively. The police are only trying to prevent violence involving the masses by preventing transcendental acts with a religious touch. Efforts to prevent the occurrence of criminal acts of mass violence committed by the National Police are to prevent the

\footnotetext{
${ }^{22}$ Argo Yuwono, Cahaya Dalam Kabut. Catatan Kerja Kabid Humas Polda Metro Jaya. Jakarta: Arsip Metro, Cet 1, Maret 2018. Page 36.
} 
occurrence of mass gathering (crowd) and abort the premise of the fourth phase of psychological mass riots by using religious Asmaul Husna forces as a way to remind and sensitize the masses as a religious moral value (transcendental) because violence is a sin and is prohibited by Allah SWT.

\section{REFERENCES}

Affandi, Hakimul Ikhwan. 2004. Akar Konflik Sepanjang Zaman: Elaborasi Pemikiran Ibn Khaldun, Yogyakarta: Pustaka Pelajar.

Bachtiar. Harsja W. 1994. Ilmu Kepolisian Suatu Cabang Ilmu Pengetahuan Baru. Jakarta: PTIK dan Grasindo.

Capra, Fritjop, 2017. dalam Suteki, The Turning Point (Science, Society, and The Rising Culture), London: Flamingo, 1983. Disampaikan Pada Seminar Nasional MIH Unissula Dengan Tema: Penanggulangan Tindakan Eigenrichting (Main Hakim Sendiri) Yang Dilakukan Oleh Kelompok Masyarakat. Semarang, 9 Desember 2017.

Charny, Israel W. 1978. Strategies against Violence: Design for Nonviolen Change. Boulder. Colorado: Westview Press. Inc.

Data Pusat Pengendali Krisis, Biro Operasional Polri, Mabes Polri. Jakarta. 2018.

Faal, M. 1991. Penyaringan Perkara Pidana Oleh Polisi. Jakarta: PT. Pradnya Paramitha.

Faudi, Munir. 2002. Perbuatan Melawan Hukum. Bandung: PT. Citra Aditya Bakti.

Galtung, John. 2004. Transcend and Transform, an Introduction to Conflict Work. London: Pluto Press.

Kamil, Ahmad. 2005. Kaidah-kaidah Hukum Yurisprudensi, Kencana, Jakarta.

Kuntowijoyo, 2004. Islam Sebagai Ilmu: Epistemologi, Metodologi dan Etika. Jakarta: Teraju PT. Mizan Publika.

Malley, Robert. 2018. Feature: 10 Conflicts to Watch in 2018. Jurnal Foreign Policy. 4 November 2018.

Nitibaskara, Ronny, 2001. Ketika Kejahatan Berdaulat: Sebuah Pendekatan Kriminologi, Hukum dan Sosiologi. Jakarta: Peradaban.

Nurcahyono, Arinto. 2003. Kekerasan Sebagai Fenomena Budaya: Suatu Pelacakan Terhadap Akar Kekerasan Di Indonesia. Jurnal Mimbar, Volume XIX No. 3 JuliSeptember 2003.

Paoletti, Giovanni. 2012. Durkheim's 'Dualism of Human Nature': Personal Identity and Social Links.Jurnal Durkheimian Studies/Études Durkheimiennes, ed. 18. 
Reksodiputro, Mardjono. 1994. Kriminologi dan Sistem Peradilan Pidana. Jakarta: PPKPH UI.

Suryakusuma, Julia L. 2003. Budaya Kekerasan, atau Budaya yang Menghasilkan Kekerasan, dalam Arinto Nurcahyono, Kekerasan Sebagai Fenomena Budaya: Suatu Pelacakan Terhadap Akar Kekerasan di Indonesia, Jurnal Mimbar, Volume XIX No. 3 Juli-September 2003.

Suseno, Franz Magnis. Etika Politik, Jakarta: Gramedia. 1987.

Soekanto, Soerjono. 2004. Faktor-Faktor Yang Mempengaruhi Penegakan Hukum Cetakan Kelima. Jakarta: Raja Grafindo Persada.

Smelser. Neil J, 1992. Theory of Colective Behavior, New York: A Free Press Paperback, 1971. T. Lickona, Educating for Character How Our Schools Can Teach Respect and Responsibility. New York-Toronto-London-Sydney-Auckland: Bantam Books.

Utrecht. E. 1962. Pengantar Dalam Hukum Indonesia. Jakarta: Balai Buku Ichtiar.

Van Ginneken. Jaap 1992. Crowds, Psychology, and Politics, 1871-1899. Cambridge, England, UK: Cambridge University Press.

Yuwono, Argo. 2018. Cahaya Dalam Kabut. Catatan Kerja Kabid Humas Polda Metro Jaya. Jakarta: Arsip Metro, Cet 1, Maret 2018. 